\title{
The effect of temperature treatments during 'Wielkopolski' sunflower seed imbibition and storage on plant tolerance to chilling
}

\author{
Krzysztof Górnik \\ Department of Ornamental Nursery and Seed Science \\ Research Institute of Horticulture \\ Konstytucji 3 Maja 1/3, 96-100 Skierniewice, Poland \\ e-mail: Krzysztof.Gornik@insad.pl
}

\begin{abstract}
The aim of the present study was to evaluate the effect of short-term high or low temperature treatments applied during seed imbibition on plant tolerance to chilling. Chilling tolerance was also investigated on seedlings obtained from dry seeds stored at low temperatures. Sunflower seeds (Helianthus annuus L. 'Wielkopolski') were stored at $5^{\circ} \mathrm{C}$ or $25^{\circ} \mathrm{C}$ and then subjected to low $\left(2.5^{\circ} \mathrm{C}\right.$ and $\left.5^{\circ} \mathrm{C}\right)$ or high $\left(35^{\circ} \mathrm{C}\right.$ and $\left.45^{\circ} \mathrm{C}\right)$ temperatures for two hours during imbibition. They were subsequently exposed to chilling $\left(2.5^{\circ} \mathrm{C}\right)$ for three weeks. Afterwards, the seeds were transferred to $25^{\circ} \mathrm{C}$ for chilling injury evaluation or sown in pots and grown in the field for further growth investigation.

The obtained results indicate that the sunflower seedlings, obtained from dry seeds stored at $25^{\circ} \mathrm{C}$, were chilling sensitive to an exposure of $2.5^{\circ} \mathrm{C}$ for three weeks, which was manifested by slow root elongation, external root discoloration and a long Mean Emergence Time (MET). The storage of dry seeds at $5^{\circ} \mathrm{C}$ reduced seedling injuries exhibited by external root discoloration and increased chlorophyll content in leaves. Short-term (two-hour) low $\left(2.5\right.$ and $\left.5^{\circ} \mathrm{C}\right)$ or high $\left(35\right.$ and $\left.40^{\circ} \mathrm{C}\right)$ temperature treatments applied to the moistened seeds alleviated chilling effects, stimulating root elongation, limiting external root discoloration and shortening MET, accelerating plant flowering and seed maturation time, increasing the diameter and weight of the anthocarp as well as seed yield and chlorophyll content.

The positive response of these methods in respect to an increase in sunflower plant tolerance to chilling indicates a possibility of their application in practice.
\end{abstract}

Key words: Helianthus annuus L., high temperature, low temperature, stress

\section{INTRODUCTION}

Sunflower is one of the most important annual crops in the world grown for its edible oil. However, in Poland the cultivation of oilseed cultivars is strongly limited by unfavourable weather conditions during the autumn and long vegetation period (Muśnicki and Toboła 1996, Górnik 2006). One of the possible ways to extend the vegetation period and thereby improve sunflower seed quality is early seed sowing. However, even cold springs with non-freezing temperatures can significantly delay sunflower seedling emergence and plant growth as well as seriously cause plant chilling injury and infection by diseases (Muśnicki and Toboła 1996).

To overcome these problems, the seedling should be made more resistant to low temperatures during early spring. Many approaches have been tried to reduce chilling injury of growing plants (Mangrich and Saltveit 2000, Kang and Saltveit 2001, Saltveit 2001). These methods include: temperature conditioning, storage at high relative 
humidity or low pressure, application of specific chemical formulation, intermittent warming, use of controlled atmospheres during chilling, increased atmospheric carbon dioxide levels, pre-treatments with calcium or ethylene, and conditioning near the chilling temperature before storage. More recently, the effects of exposure to elevated temperatures (i.e. temperature shock, heat shock or cold shock) have been shown to induce tolerance to injury from low temperatures (Collins et al. 1993, Mangrich and Saltveit 2000, Kang and Saltveit 2001, Saltveit 2001). However, these methods were mainly used during the early growth of plants, which creates difficulties in applying them in practice, during seed production. Therefore, it would be very useful if the positive effects of these methods could be applied during seed imbibition, before the radicles protrude the seed coating. Due to a lack of information on the subject, the aim of the present study was to evaluate the ability of low or high temperature treatments applied during seed imbibition or low temperature storage of dry seeds to improve plant tolerance to negative chilling effects.

\section{MATERIAL AND METHODS}

'Wielkopolski' commercial sunflower seeds (Helianthus annuus subsp. sativus) were obtained from HR Strzelce Sp. z o.o from Borowo. Sunflower seed lots were kept at $30 \% \mathrm{RH}$ and two thermal storage conditions. In the first one, they were kept at $25^{\circ} \mathrm{C}$ - these were considered the control seeds. The second ones were kept at $5^{\circ} \mathrm{C}$ for six months. Both the control seeds and the seeds stored at $5^{\circ} \mathrm{C}$ were sown in Petri dishes and moistened with distilled water at $25^{\circ} \mathrm{C}$ and prepared for chilling injury evaluation and further growth.

A portion of the seeds stored at $25^{\circ} \mathrm{C}$ was imbibed for 17 hours in darkness at the same temperature. They were then subjected to temperature treatments of 2.5 and $5^{\circ} \mathrm{C}$ (cold shock) or 35 and $40^{\circ} \mathrm{C}$ (heat shock) for 2 hours. Then, the germinating seeds were transferred to the optimal temperature of $25^{\circ} \mathrm{C}$.

All of the above treatments, i.e. the control seeds, seeds stored at $5^{\circ} \mathrm{C}$ as well as seeds subjected to different temperature treatments, were germinated until the radicles reached $5 \mathrm{~mm}$ in length and subsequently exposed to chilling at $2.5^{\circ} \mathrm{C}$ for three weeks. Afterwards, one portion of the chilled seeds was transferred to $25^{\circ} \mathrm{C}$ for three days. The root length and the percentage of their external discoloration (seedling injuries) were measured and counted. The remaining seeds were sown in pots in a peat and sand medium $(1: 1)$ at $15^{\circ} \mathrm{C}$ for three weeks and then planted in the field.

The inhibition of root growth expressed by its length after chilling as well as external root discoloration were used as indicators of the severity of chilling injury. The mean emergence time (MET) of the seedlings (days), dynamics of plant growth, chlorophyll content expressed as the chlorophyll content index (CCI), the beginning of plant flowering and maturation of seeds, the diameter and weight of the anthocarp as well as seed yield were investigated. The measurements of CCI were conducted 127 days after seed sowing by a CCM200 Chlorophyll Content Meter. The MET was calculated according to the formula MET $=\mathrm{n} \times \mathrm{d} \times$ $\mathrm{N}^{-1}$, where $\mathrm{n}=$ number of emerged seedlings each day, $d=$ number of days from the beginning of the test, and $\mathrm{N}=$ total number of all emerged seedlings. The dynamics of plant growth was measured by measurements of plant height every 7-14 days.

The experiment was designed in three replications, each comprising ten plants. The differences between the means were estimated by the Duncan multiple range test at the significance level of $p=0.05$.

\section{RESULTS AND DISCUSSION}

Previous studies had indicated that the optimal temperature for the growth of sunflower roots and hypocotyls was $25^{\circ} \mathrm{C}$. Temperatures higher and lower than optimal remarkably inhibited the growth of seedlings (Górnik et al. 2006).

The present research showed that sunflower seedlings was chilling sensitive to an exposure of $2.5^{\circ} \mathrm{C}$ for three weeks (Tab. 1). This was especially visible in the case of seedlings obtained from seeds stored in dry conditions at $25^{\circ} \mathrm{C}$ (control) and was manifested by the slowest root elongation compared with other temperature treatments. This parameter is commonly used as one of best indicators for the evaluation of chilling injury severity (Jennings and Saltveit 1994, Mangrich and Saltveit 2000, Kang and Saltveit 2001, Saltveit 2001). Sunflower hypocotyls were not as sensitive to chilling as their roots (Górnik et al. 2006). The high sensitivity of young control seedlings to chilling conditions was also confirmed by long MET and 43\% external root discoloration, which was regarded as seedling injury (Tab. 1).

The storage of dry seeds at $5^{\circ} \mathrm{C}$ did not significantly affect the length of roots and MET but remarkably reduced seedling injury manifested by external root discoloration (Tab. 1). Apparently, the latter parameter was the first signal of the influence 
Table 1. The effect of dry seed storage at optimal $\left(25^{\circ} \mathrm{C}-\right.$ control $)$ and low $\left(5^{\circ} \mathrm{C}\right)$ temperature or treatments of imbibed seeds with low $\left(2.5\right.$ and $\left.5^{\circ} \mathrm{C}\right)$ or high $\left(35\right.$ and $\left.40^{\circ} \mathrm{C}\right)$ temperature on the percentage of injured seedlings, the root length of and seedling emergence (MET) after chilling at $2.5^{\circ} \mathrm{C}$ for three weeks

\begin{tabular}{lccc}
\hline $\begin{array}{l}\text { Temperature } \\
\left({ }^{\circ} \mathrm{C}\right)\end{array}$ & $\begin{array}{c}\text { Root length } \\
(\mathrm{cm})\end{array}$ & $\begin{array}{c}\text { Percentage of injured } \\
\text { seedlings }\end{array}$ & $\begin{array}{c}\text { Mean Emergence Time } \\
(\text { days })\end{array}$ \\
\hline Control & $5.95 \mathrm{a}$ & $43.2 \mathrm{~d}$ & $39.2 \mathrm{c}$ \\
\hline Seeds stored at $5^{\circ} \mathrm{C}$ & $6.11 \mathrm{ab}$ & $25.1 \mathrm{c}$ & $38.2 \mathrm{c}$ \\
\hline $2.5^{\circ} \mathrm{C}$ & $6.78 \mathrm{c}$ & $12.5 \mathrm{ab}$ & $36.6 \mathrm{~b}$ \\
\hline $5^{\circ} \mathrm{C}$ & $7.22 \mathrm{~d}$ & $15.2 \mathrm{~b}$ & $40.0 \mathrm{c}$ \\
\hline $35^{\circ} \mathrm{C}$ & $8.02 \mathrm{de}$ & $12.6 \mathrm{ab}$ & $31.0 \mathrm{a}$ \\
\hline $40^{\circ} \mathrm{C}$ & $8.17 \mathrm{e}$ & $10.5 \mathrm{a}$ & $29.6 \mathrm{a}$ \\
\hline
\end{tabular}

* Means within columns with the same letter are not significantly different at $\mathrm{p}=0.05$ according to the Duncan multiple range test

of unfavourable temperatures for root tissue development, but was not harmful for seedling emergence and the further growth of roots. In the literature, low temperature (chilling) injury has been defined as damage sustained by plant tissue subjected to non-freezing temperatures below $12^{\circ} \mathrm{C}$ (Lyons 1973). The symptoms of chilling injury include stunted growth, internal and external discoloration, the development of waterlogged or necrotic areas, and the abnormal ripening of fruits (Khan et al. 1992). Kumar and Bhatla (2006) reported that storage of dry sunflower seeds at low temperatures improved seedling tolerance to chilling and thereby indicated an acclimation of the plants.
Short-term (two hours) low $\left(2.5\right.$ and $\left.5^{\circ} \mathrm{C}\right)$ or high (35 and $40^{\circ} \mathrm{C}$ ) temperature treatments applied to the moistened seeds significantly alleviated chilling effects (Tab. 1). The best results was observed when imbibed seeds were exposed to 35 or $40^{\circ} \mathrm{C}$, because such temperature treatments considerably stimulated the growth of roots, limited chilling root injury and accelerated seedling emergence by approximately nine days compared with the control plants (Tab. 1).

Chilling conditions negatively affected the further growth of the control seedlings (Fig. 1). Compared to other treatments, they grew slowly and very little, especially after the $97^{\text {th }}$ day from seed sowing. Short-term imbibition of seeds at low or high temperatures positively influenced

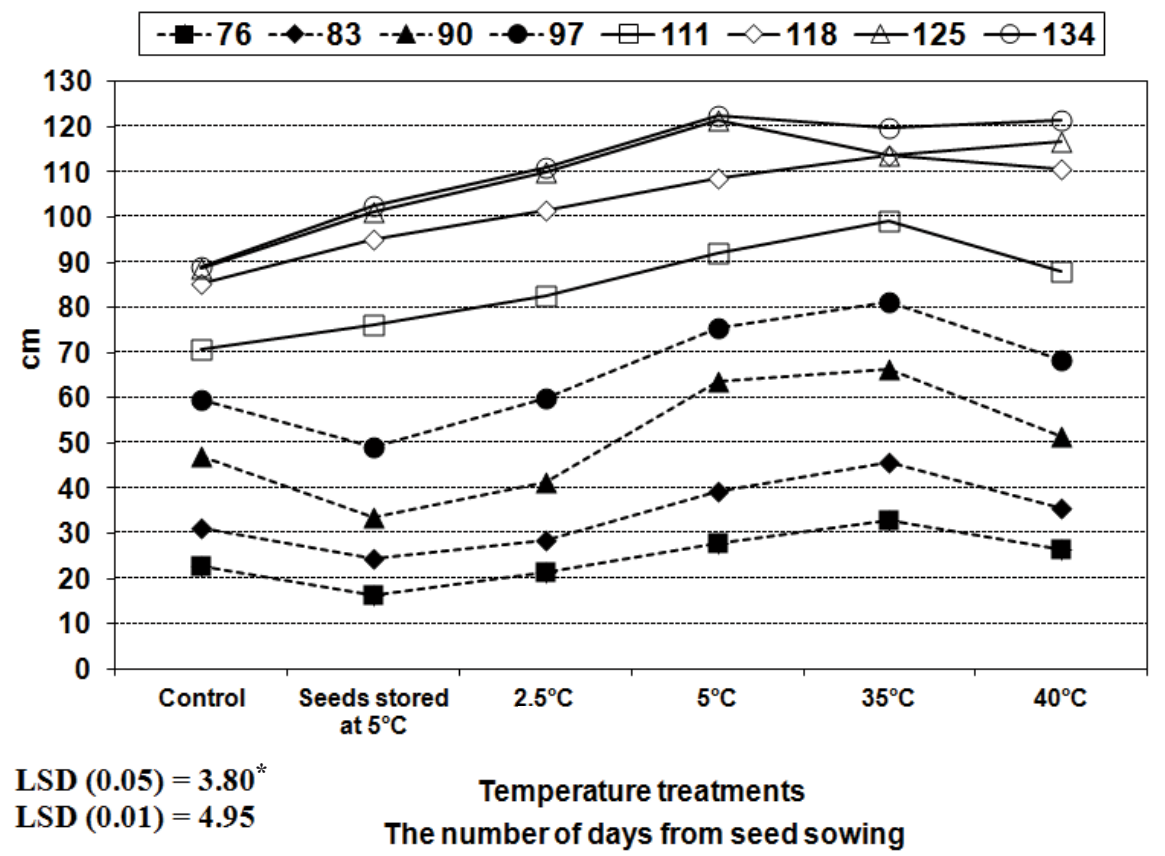

*The LSD were calculated at the significance level of $\mathrm{p}=0.01$ and 0.05 .

Figure 1. The effect of dry seed storage at $25^{\circ} \mathrm{C}$ (control) and low temperature $\left(5^{\circ} \mathrm{C}\right)$ or treatments of imbibed seeds with low $\left(2.5\right.$ and $\left.5^{\circ} \mathrm{C}\right)$ or high $\left(35\right.$ and $\left.40^{\circ} \mathrm{C}\right)$ temperatures on the dynamics of plant growth 
the growth of the plants (Fig. 1). The fastest plant growth was observed when they were obtained from seeds subjected to 5,35 or $40^{\circ} \mathrm{C}$ for two hours after imbibition at $25^{\circ} \mathrm{C}$ for 17 hours. Due to these treatments, the plants reached on average $120 \mathrm{~cm}$ after 134 days from seed sowing (Fig. 1). They were approximately $30 \mathrm{~cm}$ higher than the control plants. The positive effects of sub- and supra-optimal temperatures during China aster seed imbibition on the growth of young seedlings were observed in previous experiments (Górnik et al. 2005 a, b). Furthermore, the extent of the reaction depended not only on temperature but also on the stage of seed imbibition when the seeds were exposed to low and high temperatures (Górnik et al. $2005 \mathrm{a}, \mathrm{b}$ ).

The positive effects of the applied methods were visible in the case of diameter and weight of anthocarp as well as seed yield (Tab. 2). The most beneficial treatments were observed when seeds were subjected to $35^{\circ} \mathrm{C}$. Due to this treatment, the negative effects of the three-week chilling were reduced and as a result the plants produced almost three times as many seeds per anthocarp as the control.

Chlorophyll content in the upper control leaves was negatively affected by the three-week chilling during seedling growth (Fig. 2). It is commonly known that temperatures within the chilling range reduce photosynthesis rates in chilling injured or chilling-sensitive plants (Wang 1982). The failure to maintain photosynthesis was thought to be associated with the inability of plants to form chlorophyll at low temperatures. One apparent cause was the reduced rate of synthesis of the

Table 2. The effect of dry seed storage at optimal $\left(25^{\circ} \mathrm{C}-\right.$ control $)$ and low $\left(5^{\circ} \mathrm{C}\right)$ temperature or treatments of imbibed seeds with low $\left(2.5\right.$ and $\left.5^{\circ} \mathrm{C}\right)$ and high $\left(35\right.$ and $\left.40^{\circ} \mathrm{C}\right)$ temperature on the diameter of the sunflower anthocarp. The anthocarp weight and the weight of seeds per anthocarp after chilling at $2.5^{\circ} \mathrm{C}$ for three weeks

\begin{tabular}{lccc}
\hline $\begin{array}{l}\text { Temperature } \\
\left({ }^{\circ} \mathrm{C}\right)\end{array}$ & $\begin{array}{c}\text { Sunflower anthocarp } \\
\text { diameter }(\mathrm{cm})\end{array}$ & $\begin{array}{c}\text { Anthocarp weight } \\
(\mathrm{g})\end{array}$ & $\begin{array}{c}\text { Weight of seeds per anthocarp } \\
(\mathrm{g})\end{array}$ \\
\hline Control & $12.03 \mathrm{a}^{*}$ & $112.91 \mathrm{a}$ & $23.45 \mathrm{a}$ \\
\hline Seeds stored at $5{ }^{\circ} \mathrm{C}$ & $12.53 \mathrm{ab}$ & $114.45 \mathrm{a}$ & $24.25 \mathrm{a}$ \\
\hline $2.5^{\circ} \mathrm{C}$ & $15.49 \mathrm{c}$ & $107.85 \mathrm{a}$ & $46.53 \mathrm{c}$ \\
\hline $5^{\circ} \mathrm{C}$ & $13.52 \mathrm{~b}$ & $176.93 \mathrm{~b}$ & $38.83 \mathrm{~b}$ \\
\hline $35^{\circ} \mathrm{C}$ & $17.51 \mathrm{~d}$ & $333.25 \mathrm{~d}$ & $61.43 \mathrm{~d}$ \\
\hline $40^{\circ} \mathrm{C}$ & $15.33 \mathrm{c}$ & $226.02 \mathrm{c}$ & $50.42 \mathrm{c}$ \\
\hline
\end{tabular}

*Explanation: see Table 1

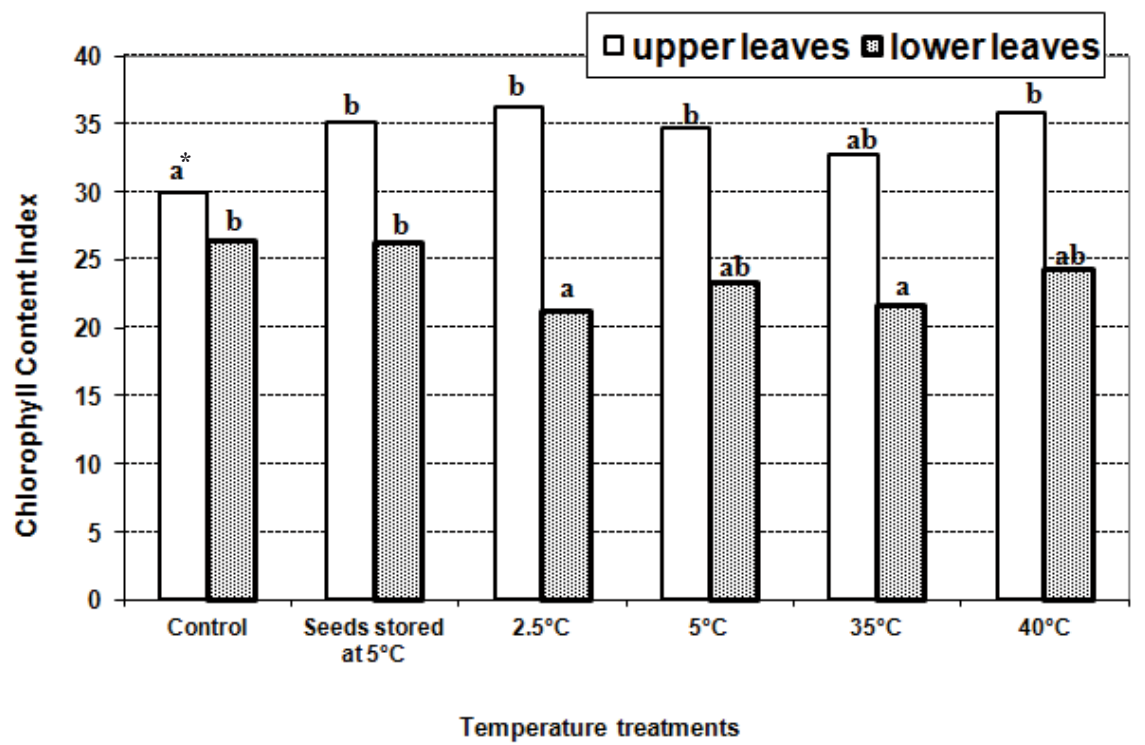

*Means within the same location of leaves on the plant and with the same letter are not significantly different at $\mathrm{p}=0.05$ according to the Duncan multiple range test

Figure 2. The effect of dry seed storage at $25^{\circ} \mathrm{C}$ (control) and low temperature $\left(5^{\circ} \mathrm{C}\right)$ or treatments of imbibed seeds with low $\left(2.5\right.$ and $\left.5^{\circ} \mathrm{C}\right)$ and high $\left(35\right.$ and $\left.40^{\circ} \mathrm{C}\right)$ temperature on chlorophyll content $(\mathrm{CCI})$ in leaves 


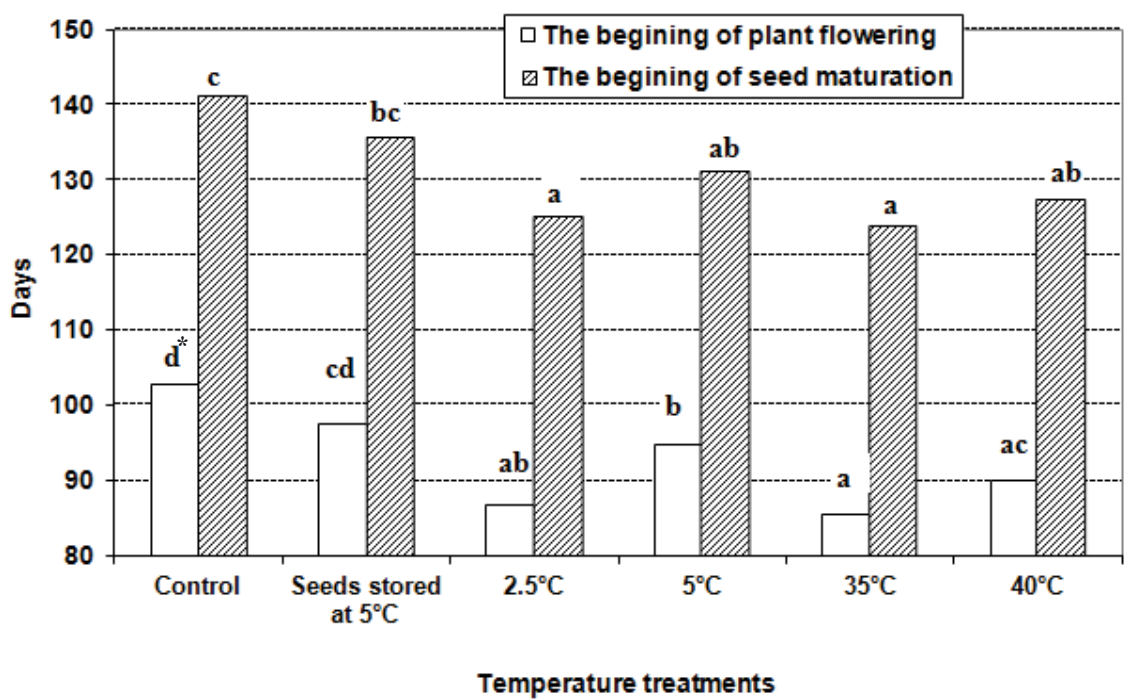

*Means within the same growth stage and with the same letter are not significantly different at $\mathrm{p}=0.05$ according to the Duncan multiple range test

Figure 3. The effect of dry seed storage at $25^{\circ} \mathrm{C}$ (control) and low temperature $\left(5^{\circ} \mathrm{C}\right)$ or treatments of imbibed seeds with low $\left(2.5\right.$ and $\left.5^{\circ} \mathrm{C}\right)$ and high $\left(35\right.$ and $\left.40^{\circ} \mathrm{C}\right)$ temperature on the beginning of plant flowering and seed maturation

precursor protochlorophyllide and its subsequent photo-oxidation (Wang 1982). In the present study, chilling was applied before the seedlings developed leaves. Therefore, low chlorophyll content in leaves was a consequence of chilling injury during seedling growth. The opposite response to chilling was observed in leaves located on the lower part of plants. This was apparently associated with the advanced process of plant maturation and thereby chlorophyll decomposition after 127 days from seed sowing. It was especially visible in the case of $5^{\circ} \mathrm{C}$ and $35^{\circ} \mathrm{C}$ temperature seed treatments.

The negative effects of chilling on chlorophyll content in leaves were also significantly alleviated due to the short-term imbibition of seeds at low or high temperatures as well as the storage of dry seeds at $5^{\circ} \mathrm{C}$ (Fig. 2). However, these observations concerned only leaves located in the upper part of the plants. Almost all temperature treatments significantly increased chlorophyll content in upper leaves. These leaves contained on average 5 CCI more than the control plants.

Both the plant flowering and seed maturation times were also beneficially affected by all temperature treatments, including storage of dry seeds at $5^{\circ} \mathrm{C}$ compared with the control plants (Fig. 3). The best treatments were observed when moistened seeds were exposed to 2.5 or $35^{\circ} \mathrm{C}$. After such applications, plant flowered and seed matured approximately 15 days earlier that the control plants obtained from seeds stored at $25^{\circ} \mathrm{C}$. The inductive influence of low temperatures on the flowering of
China aster plants was also significantly visible in previous experiments conducted by Górnik et al. (2005 b).

The obtained results indicate the possibility of the application of these methods in practice. Moreover, the examined methods are relatively cheap and can be applied in seed companies during seeds conditioning, i.e. matriconditioning or hydroconditioning. However, further experiments on other cultivars should be performed to confirm the obtained results.

\section{CONCLUSIONS}

1. Sunflower seedlings obtained from control seeds stored at $25^{\circ} \mathrm{C}$ were chilling sensitive to an exposure of $2.5^{\circ} \mathrm{C}$ for three weeks, which was manifested by slow root elongation, external root discoloration and long MET.

2. Short-term (two hours) low $\left(2.5\right.$ and $\left.5^{\circ} \mathrm{C}\right)$ or high $\left(35\right.$ and $\left.40^{\circ} \mathrm{C}\right)$ temperature treatments applied to the moistened seeds alleviated chilling effects, i.e. it stimulated root elongation, limited external root discoloration and shortened MET, accelerated plant flowering and seed maturation time and increased the diameter and weight of the anthocarp as well as seed yield and chlorophyll content.

3. Storage of dry seeds at $5^{\circ} \mathrm{C}$ reduced seedling injury manifested by external root discoloration and increased chlorophyll content in leaves. 


\section{REFERENCES}

Collins G.G., Nie X.L., Saltveit M.L., 1993. Heat shock increases chilling tolerance of mung bean hypocotyl tissue. Physiol. Plant. 89(1): 117-124.

GóRniK K., 2006. Słonecznik - roślina o dużym znaczeniu gospodarczym. Zesz. Nauk. WSE-H w Skierniewicach 5: 27-36.

Górnik K., Grzesik M., Chojnowska E., 2005 a. The effect of high temperature treatments during seed imbibition on their germination and growth of China aster 'Perła Biała'. Zesz. Probl. Post. Nauk Roln. 504(2): 585-592.

Górnik K., Grzesik M., Chojnowska E., 2005 b. Wpływ niskiej temperatury $\mathrm{w}$ fazie pęcznienia nasion na wschody siewek oraz rozwój roślin astra chińskiego. In: Zmienność genetyczna - utrzymanie, tworzenie i wykorzystanie w hodowli roślin. B. Michalik and E. Żurawicz (eds), Monografia. Instytut Sadownictwa i Kwiaciarstwa oraz Sekcja Hodowli Roślin i Nasiennictwa PTNO: 395-400.

Górnik K., Grzesik M., Chojnowska E., 2006. Wpływ temperatury na wschody i rozwój słonecznika zwyczajnego „Sonnengold”. Zesz. Probl. Post. Nauk Roln. 510(1): 159-166.

Jennings P., Saleveit M.E., 1994. Temperature effects on imbibition and germination of cucumber (Cucumis sativus) seeds. J. Am. Soc. Hort. Sci. 119: 464-467.

Kang H., Saltveit M.E., 2001. Activity of enzymatic antioxidant defense systems in chilled and heat shocked cucumber seedling radicals. Physiol. Plant. 113: 548-556.

Khan A.A., Maguire J.D., Abawi G.S., Ilyas S., 1992. Matriconditioning of vegetable seeds to improve stand establishment in early field plantings. J. Am. Soc. Hort. Sci. 117: 41-47.

Kumar A., Bhatla S.C., 2006. Polypeptide markers for low temperature stress during seed germination in sunflower. Biol. Plant. 50(1): 81-86.

Lyons J.M., 1973. Chilling injury in plants. Ann. Rev. Plant Physiol. 24: 445-466.

Mangrich M.E., Saltveit M.E., 2000. Effect of chilling, heat shock, and vigour on the growth of cucumber (Cucumis sativus) radicles. Physiol. Plant. 109(2): 137-142.

Muśnicki C., ToвoŁA P., 1996. Słonecznik - mało znana w Polsce roślina oleista. Top Agrar Polska 4: 30-33.

SAltveit M.E., 2001. Chilling injury is reduced in cucumber and rice seedlings and in tomato pericarp discs by heat-shocks applied after chilling. Postharvest Biol. Technol. 21: 169-177.

WANG C.Y., 1982. Physiological and biochemical responses of plants to chilling stress. HortScience 17: 2 .

\section{WPLYW TEMPERATURY PODCZAS} PRZECHOWYWANIA ORAZ PECZNIENIA NASION SŁONECZNIKA NA ODPORNOŚĆ ROŚLIN NA CHŁÓD

Streszczenie: Celem badań była ocena wpływu krótkiego oddziaływania niskiej lub wysokiej temperatury podczas pęcznienianasionnaodporność wyrosłych z nich roślin na chłód. Ocena odporności na niskie temperatury była przeprowadzona również na siewkach pochodzących $\mathrm{z}$ suchych nasion przechowywanych $\mathrm{w}$ niskiej temperaturze. Nasiona słonecznika (Helianthus annuus L. 'Wielkopolski') przechowywano $\mathrm{w} 5^{\circ} \mathrm{C}$ lub $25^{\circ} \mathrm{C}$, a następnie podczas kiełkowania przeniesiono do niskiej $\left(2,5^{\circ} \mathrm{C}\right.$ i $\left.5^{\circ} \mathrm{C}\right)$ lub wysokiej temperatury $\left(35^{\circ} \mathrm{C}\right.$ i $\left.45^{\circ} \mathrm{C}\right)$ na 2 godziny. Nasteppnie schładzano je w $2,5^{\circ} \mathrm{C}$ przez 3 tygodnie. Po schłodzeniu kiełkujące nasiona przeniesiono na $3 \mathrm{dni}$ do $25^{\circ} \mathrm{C}$ w celu oceny uszkodzeń siewek spowodowanych przez chłód lub wysiano do doniczek i przesadzono do gruntu w celu oceny dalszego wzrostu roślin. Uzyskane wyniki wskazały, że siewki kontrolne, pochodzące $\mathrm{z}$ suchych nasion przechowywanych $\mathrm{w} 25^{\circ} \mathrm{C}$, były wrażliwe na oddziaływanie trzytygodniowego chłodu $\left(2,5^{\circ} \mathrm{C}\right)$. Objawiało się to wolnym wzrostem korzeni, ich przebarwieniami i długim okresem wschodów siewek. Przechowywanie suchych nasion w $5^{\circ} \mathrm{C}$ zmniejszyło negatywny wpływ chłodu, co wyrażało się mniejszymi przebarwieniami korzeni oraz zwiększoną zawartością chlorofilu w liściach. Krótkie oddziaływanie niskiej $\left(2,5\right.$ i $\left.5^{\circ} \mathrm{C}\right)$ lub wysokiej temperatury $\left(35 \mathrm{i} 40^{\circ} \mathrm{C}\right)$ podczas pęcznienia nasion łagodziło niekorzystny wpływ chłodu. Wyrażało się to mniejszymi uszkodzeniami siewek oraz ich dłuższymi korzeniami w porównaniu do nasion nawilżanych w przez cały okres pęcznienia w $25^{\circ} \mathrm{C}$. Krótkotrwałeoddziaływanietych temperatur również znacznie przyspieszyło wschody siewek, wzrost roślin, termin kwitnienia roślin i dojrzewania nasion, jak również zwiększyło zawartość chlorofilu w roślinach, średnicę i masę owocostanu oraz plon nasion. Pozytywny wpływ stosowanych metod zwiększających odporność roślin słonecznika na chłód wskazuje na możliwość stosowania tych metod w praktyce. Dla potwierdzenia tych wyników planowane są dalsze badania na innych odmianach słonecznika.

Received September 16, 2010; accepted November 16, 2011 